\title{
Cloning, mapping and nucleotide sequencing of a gene encoding a universal stress protein in Eschericha coli
}

Thomas Nyström* and Frederick C. Neidhardt Department of Microbiology and Immunology, University of Michigan Medical School, 6643 Medical Science Building II, Ann Arbor, Michigan 48109-0620, USA.

\section{Summary}

The response of non-differentiating bacteria to nutrient starvation is complex and includes the sequential synthesis of starvation-inducible proteins. Although starvation for different individual nutrients generally provokes unique and individual patterns of protein expression, some starvation stimulons share member proteins. Two-dimensional polyacrylamide gel electrophoresis revealed that the synthesis of a small (13.5 kDa) cytoplasmic protein in Escherichia coli was greatly increased during growth inhibition caused by the exhaustion of any of a variety of nutrients (carbon, nitrogen, phosphate, sulphate, required amino acid) or by the presence of a variety of toxic agents including heavy metals, oxidants, acids and antibiotics. To determine further the mode of regulation of the protein designated UspA (unniversal stress protein A) we cloned the gene encoding the protein by the technique of reverse genetics. We isolated the protein from a preparative two-dimensional polyacrylamide gel, determined its $\mathrm{N}$-terminal amino acid sequence, and used this sequence to construct a degenerate oligonucleotide probe. Two phages of the Kohara library were found to contain the gene which then was subcloned from the DNA in the overlapping region of these two clones. The amino acid sequence, deduced from the nucleotide sequence of the uspA gene, shows no significant homology with any other known protein. The uspA gene maps at $77 \mathrm{~min}$ on the E. coli W3110 chromosome, and is transcribed in a clockwise direction. The increase in the level of UspA during growth arrest was found to be primarily a result of transcriptional activation of the corresponding gene. The induction was independent of the RelA/Spot, RpoH, KatF, OmpR, AppY, Lrp, PhoB and H-NS proteins during stress conditions that are known to induce or activate these global regulators.

Received 27 May; accepted 10 July, 1992. *For correspondence. Tel. (313) 763 3531; Fax (313) 7643562.
The -10 and -35 regions upstream of the transcriptional start site of the uspA gene are characteristic of a $\sigma^{70}$-dependent promoter.

\section{Introduction}

The vast majority of bacterial species are able to survive long-term periods of growth arrest in the absence of sophisticated means of morphological differentiation and sporulation (Kjelleberg et al., 1987). However, like spore formation in for example Bacillus spp., Clostridium spp., Streptomyces spp., and Hyphomicrobium spp., and fruiting-body formation in Myxococcus spp., the response of Escherichia coli during a transition from growth to stasis includes sequential changes in the pattern of gene expression (Groat et al., 1986; Lange and Hengge-Aronis, 1991a). This modulation in gene expression is accompanied by an increased resistance of $E$. coli cells to a variety of potentially harmful stresses, such as heat shock, $\mathrm{H}_{2} \mathrm{O}_{2}$ exposure (Jenkins et al., 1988; Lange and Hengge-Aronis, 1991a), and osmotic challange (Jenkins et al., 1990).

Two-dimensional (2-D) gel electrophoresis analysis of E. coli proteins induced during the cessation of growth as a result of starvation for different individual nutrients has revealed that the majority of the proteins induced by one specific starvation stimulus are generally unique to that particular stimulon (VanBogelen et al., 1990). However, starvation stimulons share member genes (Groat et al., 1986; VanBogelen et al., 1990); i.e., proteins associated with one starvation stimulon may be induced by other starvation or stress stimuli. A few of the numerous proteins reported to be induced by two or more starvation conditions are products of identified genes or members of known global regulatory networks. These proteins include exonuclease III (Sak et al., 1989), the HPII catalase (von Ossowski et al., 1991), proteins of the microcin B17 operon (Conell et al., 1987), proteins of the ftsQAZ gene cluster (Aldea et al., 1990), the product of the bolA morphogene (Aldea et al., 1990; Lange and Hengge-Aronis, 1990b), proteins stimulating glycogen synthesis (Lange and Hengge-Aronis, 1991a), the nucleoid protein H-NS (VanBogelen et al., 1990; Spaasky et al., 1984), the putative starvation-inducible sigma factor encoded by the katF gene (Mulvey and Loewen, 1989; Lange and HenggeAronis, 1991a), and the GroEL, GroES, DnaK, GrpE, 


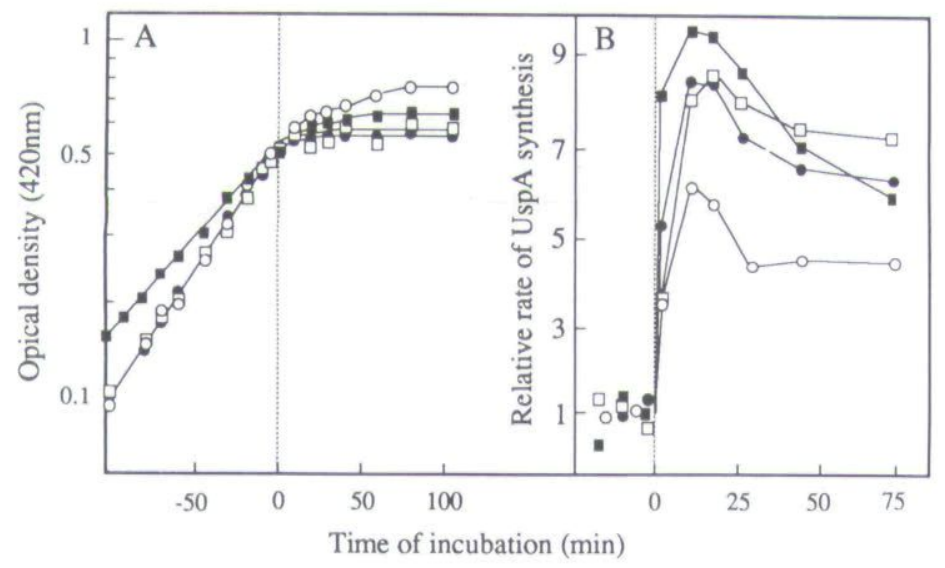

Fig. 1. A. Effect of starvation conditions on growth. Strain W3110 was grown aerobically at $37^{\circ} \mathrm{C}$ in glucose minimal MOPS or M9 (sulphate starvation) with one-twentieth the normal concentration of glucose (-), phosphate (O), nitrogen $(\square)$, or sulphate (ש). The time at which a change in the growth rate was observed was designated time zero of starvation. B. Time-course of induction of protein UspA during starvation for glucose (•), phosphate (O), nitrogen $(\square)$, or sulphate (ש). A portion of the culture was labelled for $5 \mathrm{~min}$ at exponential growth and at intervals after a change in the growth rate was observed. The differential rates of UspA synthesis were determined as described in the Experimental procedures. All rates are plotted relative to the differential rate prior to starvation-induced growth inhibition, which was defined as 1.0.
$\mathrm{HtpH}$, and HtpM proteins of the heat-shock response (VanBogelen et al., 1990). In contrast to proteins induced by the exhaustion of one specific nutrient, which seem to be specifically involved with enhancing the cell's capacity of assimilation and uptake of the particular limiting factor (Ullman and Danchin, 1983; Magasanik and Neidhardt, 1987; Wanner, 1987), these general starvation proteins may have more general protective functions related to the growth arrest state.

In the present study we demonstrate that cells of $E$. coli greatly increase the synthesis of a small $(13.5 \mathrm{kDa})$ protein as soon as the cell growth rate falls below the maximal growth rate supported by the medium, regardless of the condition inhibiting growth. So far, 15 different starvation and stress conditions, including exposure to heavy metals, oxidants, and antibiotics, have been demonstrated to induce the synthesis of this protein three- to ninefold. The protein is made at easily detected levels during unrestricted, steady-state growth, but is rapidly induced by growth inhibition. The gene, designated uspA (universal stress protein $\mathrm{A}$ ), encoding this protein was cloned and its DNA sequence determined. Sequence analysis revealed that the uspA gene is a previously unidentified gene located at the $77 \mathrm{~min}$ region of the $E$. coli W3110 chromosome. We report here the initial characterization of UspA expression, the structural gene, and its promoter region. Our interest in the UspA protein stems from the fact that $E$. colipossesses no other protein with so universal a property of responding to diverse stresses.

\section{Results}

Protein UspA is induced during starvation for different macronutrients

E. coli wild-type strain $\mathrm{W} 3110$ was grown at $37^{\circ} \mathrm{C}$ in minimal 3-( $\mathrm{N}$-morpholino) propanesulphonic acid (MOPS) or
M9 medium limited for either carbon (glucose), nitrogen, phosphate, or sulphate. The concentrations of the limiting nutrients were chosen so that cell growth ceased at an $\mathrm{OD}_{420}$ of about 0.5 . Portions of the cultures were labelled with $\left[{ }^{3} \mathrm{H}\right]$-leucine for $5 \mathrm{~min}$, before and at intervals after a change in the growth rate was observed, followed by 2-D gel analysis. Growth of cells and the extent of UspA induction during the depletion of the different macronutrients is depicted in Fig. 1, A and B. The responsiveness of the protein UspA was found to be essentially indistinguishable between the different starvation conditions. The rate of UspA synthesis was inceased six- to ninefold with a peak of induction within the first $20 \mathrm{~min}$ after a change in growth rate was observed (Fig. 1B). An increased rate of UspA synthesis extended throughout a carbon (glucose) starvation period of at least $8 \mathrm{~d}$ (not shown).

\section{Induction is related to growth inhibition}

Is the induction of the protein UspA primarily the result of growth arrest rather than starvation for any essential metabolite? To approach this question we used an experimental system in which growth and the cellular levels of guanosine 3'-diphosphate 5'-di(tri)phosphate (ppGpp(p)) are controlled by induction of plasmid pKK223-3 derivatives in which a portion of the relA structural gene is under control of a $\mathrm{P}_{\text {tac }}$ promoter (Schreiber et al., 1991). Induction with IPTG of the RelA protein results in the elevation in $\operatorname{ppGpp}(\mathrm{p})$, inhibition of stable RNA accumulation, and the cessation of growth (Schreiber et al., 1991). This IPTG/RelA induction system enabled us to view the effects of growth inhibition when there are no known changes in nutritional abundance. IPTG was added to $E$. coli W3110 $\mathrm{P}_{\text {tac }}:$ :relA growing in glucose-rich MOPs at an $\mathrm{OD}_{420}$ of 0.5 . Growth of the culture and the relative rate of UspA synthesis are depicted in Fig. 2, A and B. The expression of UspA increased during IPTG/RelA-induced 


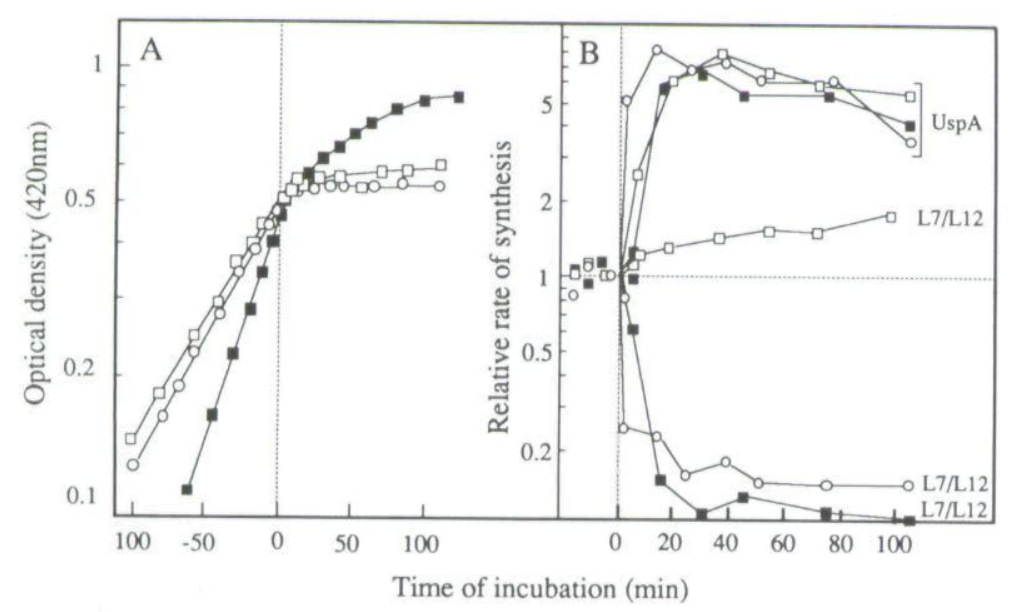

Fig. 2. Cell growth (A), and expression of UspA (B) during growth inhibition by IPTG induction of a $\mathrm{P}_{\text {tac }}$ :relA fusion ( $\left.\mathbf{\square}\right)$, carbon starvation of $\mathrm{wt}$ W3110 (O), and carbon starvation of W3110

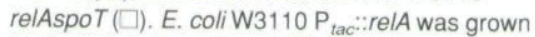
in glucose-rich medium. Wild-type W3110 and the relAspoT mutant were grown in minimal MOPS with $1 / 20$ glucose (see the Experimental procedures). The E. coli relAspoT culture was supplemented with required amino acids and grown at $28^{\circ} \mathrm{C}$. The rates of synthesis of ribosomal protein L7/L12, known to be under stringent control, were also determined. See Fig. 1 for methodology. growth inhibition to the same extent as during total starvation for carbon (glucose) (Fig. 2B). Induction during glucose starvation was independent of ppGpp accumulation since expression of UspA in a relA/spoT deletion mutant was similar to that of the isogenic parent (Fig. 2B). The induction of UspA during isoleucine starvation and starvation for charged seryl-tRNA, as a result of serine hydroxamate (SHMT) addition to cell cultures, was also demonstrated to be relA/spoT-independent (not shown). Furthermore, nine additional stress conditions (hydrogen peroxide, 6-amino-7-chloro-5,8-dioxoquinoline (ACDQ), dinitrophenol (DNP), nalidixic acid, cycloserine, and $\mathrm{CdCl}_{2}$ treatment, heat, acid and osmotic shock) causing growth inhibition were subsequently demonstrated to induce significantly the expression of UspA. These results suggest that the induction of UspA is attributed to inhibition of balanced, unrestricted growth rather than to starvation for any key metabolite.

\section{Mutations in various global regulatory loci do not affect induction of UspA}

Since several of the stress conditions used are known to induce or activate global control networks, we asked whether uspA is regulated by any or several of the known master regulators of these networks. To address this question, we examined the effects of mutations in a number of global regulatory loci on UspA expression. The loci studied include the relA/spoT genes responsible for ppGpp accumulation during amino acid and carbonenergy starvation (Gallant, 1975; Metzger et al., 1989), the phoB gene involved in the regulation of the phosphate limitation regulon (Wanner, 1987), the katF gene encoding a putative starvation-inducible sigma factor (Mulvey and Loewen, 1989; Lange and Hengge-Aronis, 1991a), the app $Y$ locus which, when cloned in high copy-number, affects growth phase-dependent expression of several genes (Atlung et al., 1989), the Irp gene proposed to be involved in the adaptation of $E$. coli to major shifts in the environment (Ernsting et al., 1992), the ompR gene regulating gene expression during changes in medium osmolarity (Hall and Silhavy, 1981) and required for the growth phase-dependent regulation of the $m c b A$ gene (Conell et al., 1987), the $r p o H$ gene encoding $\sigma^{32}$ of the heat-shock response (Neidhardt et al.,1984), and the hns (osmZ) locus implicated in the regulation of general stress proteins and growth phase-dependent protein expression by means of altering DNA superhelicity (Higgins et al., 1988). As shown in Table 1, the mutations in these loci did not affect the synthesis of protein UspA during conditions known to induce or activate these regulators. Thus, the UspA protein could not be assigned membership in any of the global regulons included in this study. In addition, the UspA protein is not overproduced in an E. coli oxyR2 which is constitutive for expression of the oxidative stress regulon (R. VanBogelen, personal communication).

\section{Rate of UspA synthesis is not related to growth rate in steady state}

The increase in UspA expression levels seemed to be initiated as soon as the growth rate began to fall below the maximal growth rate supported by the medium (Figs 1 and 2). Thus, it is possible that the gene encoding protein UspA may, in fact, be regulated by growth rate so that expression from the promoter is inversely correlated to growth rate. To test this hypothesis, we measured the relative rate of UspA production in E. coli W3110 growing at different growth rates in MOPS minimal media supplemented with different carbon sources (Wanner et al., 1977). The rates of UspA synthesis in the different media 
Table 1. Expression of UspA in response to different environmental stimuli in wild type (wt) $E$. coli (W3110) and in global regulatory mutants. + indicates that the protein spot has been quantitatively determined to be induced threefold or more. nd, not determined. For detailed description of the environmental conditions, refer to the Experimental procedures. The complete genotypes of the strains are listed in Table 1.

\begin{tabular}{|c|c|c|c|c|c|c|c|c|c|}
\hline \multirow[b]{2}{*}{$\begin{array}{l}\text { Environmental } \\
\text { conditions }\end{array}$} & \multicolumn{9}{|c|}{ Strains/(Relevant genotype) } \\
\hline & $\begin{array}{l}\text { W3110 } \\
\text { (wt) }\end{array}$ & $\begin{array}{l}\text { BW3820 } \\
(p h o B)\end{array}$ & $\begin{array}{l}\text { CF1948 } \\
\text { (relA } \\
\text { spot) }\end{array}$ & $\begin{array}{l}\text { UM122 } \\
\text { (katF) }\end{array}$ & $\begin{array}{l}\text { TC3617 } \\
(\text { appY) }\end{array}$ & $\begin{array}{l}\text { ZK242 } \\
\text { (ompR) }\end{array}$ & $\begin{array}{l}\text { GM230 } \\
\text { (hns) }\end{array}$ & $\begin{array}{l}\text { BE1 } \\
\text { (Irp) }\end{array}$ & $\begin{array}{l}\mathrm{K} 165 \\
(\mathrm{rpoH})\end{array}$ \\
\hline $\begin{array}{l}\text { Carbon (glucose) } \\
\text { starvation }\end{array}$ & + & nd & + & + & + & + & + & + & nd \\
\hline Phosphate starvation & + & + & nd & + & + & nd & nd & nd & nd \\
\hline Isoleucine starvation & + & nd & nd & + & nd & nd & nd & + & nd \\
\hline Serine hydroxamate & + & nd & + & nd & nd & nd & nd & nd & nd \\
\hline Cadmium chloride & + & nd & + & nd & nd & nd & nd & nd & + \\
\hline Osmotic stress & + & nd & nd & nd & nd & + & + & nd & nd \\
\hline Heat shock & + & nd & + & nd & nd & nd & nd & nd & + \\
\hline
\end{tabular}

were determined by quantification of pulse-labelled proteins after 2-D gel electrophoresis. While the UspA protein was found to be somewhat repressed during growth in glucose-rich MOPS, the expression was essentially independent of growth rate below a specific growth-rate constant $(k)=0.7$ (Fig. 3 ). It is thus feasible that perturbation of balanced growth rather than slow growth rate per se determines the expression of the UspA protein.

\section{The uspA gene has been cloned, mapped, and its nucleotide sequence determined}

To determine further the mode of regulation of the UspA protein we cloned the gene encoding the protein by the technique of reverse genetics. To synthesize a DNA probe complementary to a nucleotide sequence in the uspA gene, a partial $\mathrm{N}$-terminal amino acid sequence of the protein was obtained. The UspA protein was induced for $1 \mathrm{~h}$ by IPTG induction of the RelA protein in the $E$. coli $\mathrm{P}_{\text {tac }}:$ : relA construct described in preceding sections. The extent of induction and the location of the UspA protein on a standard 2-D gel are shown in the autoradiograms in Fig. 4. After transfer of proteins by electroelution to polyvinylidene fluoride (PVDF) membranes, the UspA spot was identified by autoradiography and excised from the membrane. Automated Edman degradation was performed directly on membrane fragments generating a peptide with the sequence: Ala-Tyr-Lys-His-Ile-LeuIle-Ala-Val-Asp-Leu-Ser-Pro-Glu. Based on the TyrLys-His-Ile-Leu-lle-Ala part of the $\mathrm{N}$-terminal amino acid sequence the following 72 -fold degenerate oligonucleotide probe was made: 5'-TAY-AAR-CAY-ATHCTG-ATH-GC-3', where $Y$ is a pyrimidine, $R$ is a purine and $\mathrm{H}$ is $\mathrm{A}, \mathrm{T}$ or $\mathrm{C}$.

For Southern blot analysis, E. coli chromosomal DNA was digested with various restriction enzymes. Autoradiograms from Southern blot hybridizations with the degenerate oligonucleotide probe showed that the Sall digest yielded one small band of about $3.2 \mathrm{~kb}$. A Sall digest of chromosomal DNA was then fractionated by gel electrophoresis and each fraction, recovered by electroelution
(Sambrook et al., 1989), was subsequently subjected to Southern blot analysis with the probe. One fraction hybridized the probe, and the DNA from this fraction was subsequently ligated into the Sall site of pB2SK phagemid using T4 ligase. The ligation mix was then introduced into $E$. coli $\mathrm{DH} 5 \alpha \mathrm{F}^{\prime}$ by standard transformation methodology. One E. coli $\mathrm{DH} 5 \alpha \mathrm{F}^{\prime}$ transformant, designated pTN38, harbouring a chromosomal fragment complementary to the probe was identified by colony filter hybridization. A Sall-Xhol fragment of the pTN38 DNA, found by nucleotide sequencing to contain only part of the structural uspA gene, was isolated and used as a probe for screening the Kohara $\lambda$-phage library of $E$. coli W3110 genomic DNA (Takara Biochemicals Inc.) after labelling using the random primer labelling procedure (Boerhinger Mannheim Co.). Two Kohara clones, $12 E 4$ and 6A4, containing inserts of DNA mapping at about $77 \mathrm{~min}$ on the $E$.

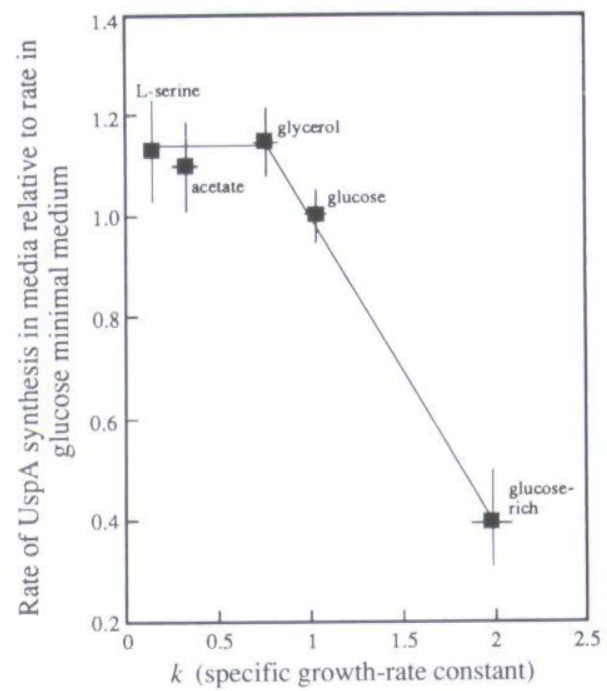

Fig. 3. Rate of UspA synthesis in E. coli at varying growth rates. Strain W3110 was grown exponentially in minimal MOPS media supplemented with L-serine, acetate, glycerol or glucose as carbon sources. Glucoserich denotes the medium supplemented with glucose, amino acids, nucleotides and vitamins. The rates of UspA synthesis are plotted relative to the rate of synthesis in glucose minimal media. Growth rates in the different media are expressed as $k$, the first-order growth-rate constant. 

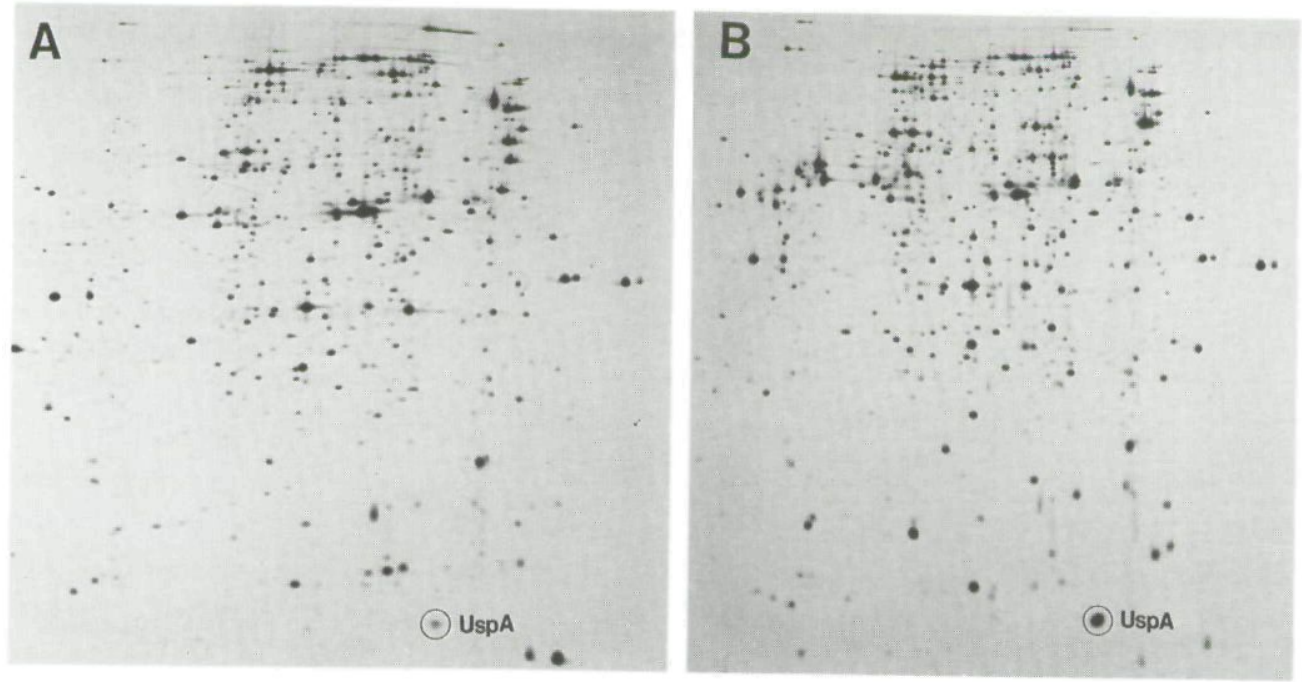

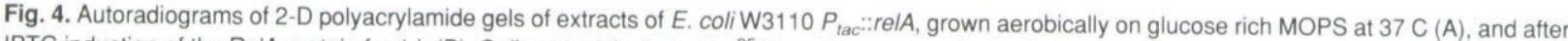
IPTG induction of the RelA protein for $1 \mathrm{~h}$ (B). Celle were labelled with $\left[{ }^{35} \mathrm{~S}\right]$-methionine for 10 min during exponential growth and $1 \mathrm{~h}$ after the addition of IPTG $(200 \mu \mathrm{M})$. The circled protein spot is UspA.

coli chromosome, bound the probe. Based on nucleotide sequence, the predicted size of uspA, and restriction enzyme digestion analysis of the pTN38 phagemid, we concluded that the entire structural usp $A$ gene was located in the $5.2 \mathrm{~kb}$ Pstl fragment of clone 6A4 in the region that overlapped these clones (Fig. 5). $\lambda$-Phage DNA was purified from Kohara clone $6 \mathrm{~A} 4$, and subcloning of the $5.2 \mathrm{~kb}$ Pstl fragment was accomplished followed by DNA sequencing of the entire uspA gene, using the Sanger dideoxy chain termination method. The map position of the uspA gene, restriction enzyme sites in the cloned Pstl fragment, known restriction sites of the 12E4 and 6A4 Kohara clones (Kohara et al., 1987), and the sequencing strategy are depicted in Fig. 5 . In vitro transcription-translation analysis of purified pTN6091 DNA was performed to monitor for the presence of the uspA gene (Fig. 6). In addition to uspA the Pstl fragment appeared to contain a gene encoding a $42 \mathrm{kDa}$ protein (Fig. 6).

The sequence of the uspA gene is shown in Fig. 7. An open reading frame with a deduced amino acid sequence generating a $15.8 \mathrm{kDa}$ protein with a pl of 5.2 was found between bases 1 and 432 , followed by what appears to be a strong rho-independent terminator. Following a ribosome-binding site (Fig. 7), the 5' end of the open reading frame begins with a methionyl residue followed by 14 residues identical to those obtained by Edman degradation of the purified UspA protein.

\section{Regulation of the uspA gene is transcriptional}

In order to determine whether regulation of the uspA gene was at the transcriptional or post-transcriptional level, we isolated RNA from exponentially growing E. coli W3110 cells (glucose-limited MOPS, $37^{\circ} \mathrm{C}$ ), cells depleted for carbon (glucose), and starved cells subjected to an upshift (glucose addition). The RNA was processed for Northern blot analysis using a $\left[\alpha^{-{ }^{32}} \mathrm{P}\right]$-CTP labelled Pvull-Mscl DNA fragment of the pTN6091 subclone (Fig. 5 ) as a probe for the uspA transcript. Results of this experiment are shown in Fig. 8 , in which the growth of the cells, relative rate of UspA synthesis, and amount of uspA transcript as determined by Northern analysis, are recorded. As shown in this Figure, the uspA transcript rapidly accumulated in the cells in response to growth arrest. Furthermore, the synthesis of the uspA transcript was quickly shut off as a result of glucose addition (Fig. 8C). In fact, the uspA transcript could not be detected $20 \mathrm{~min}$ after the resupply of glucose to starved cells (Fig. $8 \mathrm{C}$ ). Measurement of the functional half-life of the uspA transcript during non-inducing and inducing conditions indicated that differential control of mRNA stability in response to growth inhibition could not constitute the mechanism behind the accumulation of uspA transcripts. The functional half-life of the uspA transcript increased from 1.8 min during steady-state growth in glucose minimal MOPS to $2.7 \mathrm{~min}$ after $30 \mathrm{~min}$ of glucose starvation (Fig. 9). However, the half-life of control transcripts, tufA and $o m p F$, as well as the functional half-life of the total mRNA pool increased by the same factor.

\section{UspA stability during steady-state growth and glucose starvation does not account for its regulation}

In parallel with the uspA transcript studies, we measured the stability of the UspA protein during the conditions 


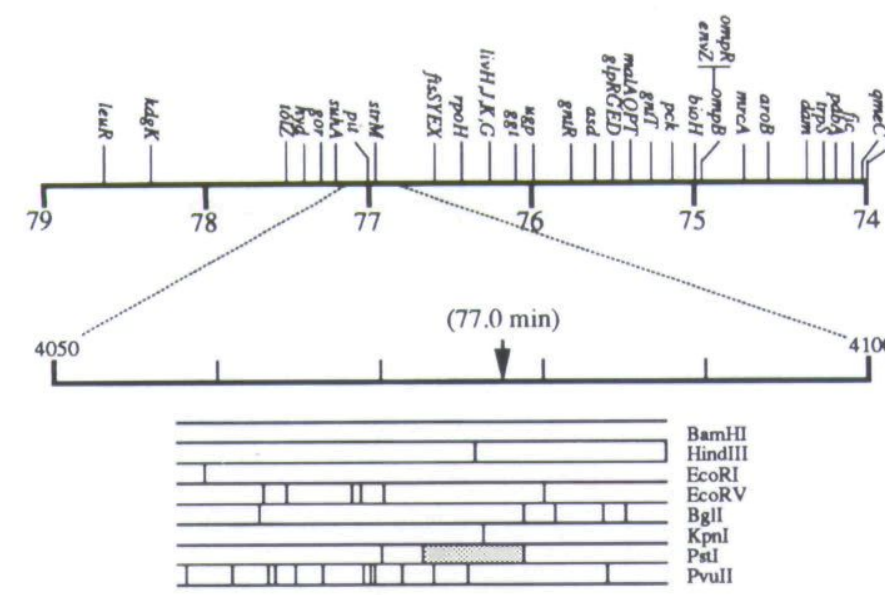

$\min$ from $t h r$

kb from $t h r$

Fig. 5. Location of the uspA gene on the $E$. coli W3110 chromosome, in the insert of Kohara phages $12 \mathrm{E} 4$ and $6 \mathrm{~A} 4$, the $5.2 \mathrm{~kb} P$ stl fragment of clone pTN6091, and the $1.1 \mathrm{~kb}$ Pstl-Sacll fragment of clone pTN6094. The linkage map of the E. coli chromosome between 74 and $79 \mathrm{~min}$ from thr is adapted from Bachmann (1990). Restriction map of Kohara phages $12 \mathrm{E} 4$ and $6 \mathrm{~A} 4$ is adapted from Kohara et al. (1987). Restriction enzyme digestion analysis of pTN6091 and 6094 is depicted in the Figure together with the sequence strategy of clone pTN6094.

$12 \mathrm{E} 4$

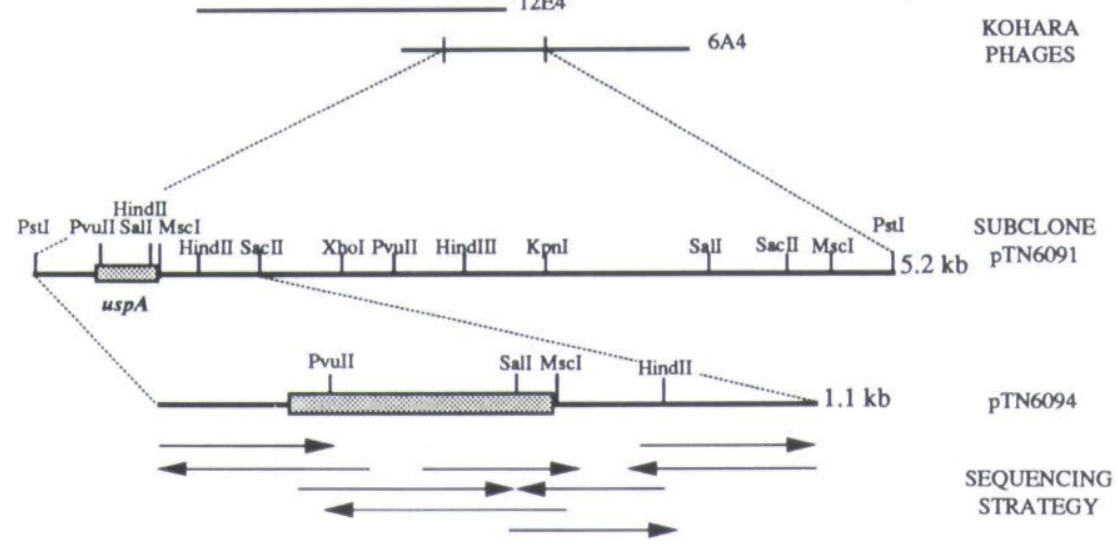

RESTRICTION MAP

described in Fig. 8A. The results of these experiments, described in the Experimental procedures, indicated that about $15 \%$ of the protein is degraded in $3 \mathrm{~h}$ regardless of whether the cells were growing exponentially, were starved for glucose, or subjected to glucose upshift conditions (Fig. 10).

\section{The uspA promoter has been determined}

In order to identify the start point of the uspA transcript, we conducted primer extension analysis of $E$. coli RNA isolated from cells in steady-state growth and at intervals after glucose exhaustion. Several primers complementary to the uspA coding strand generated the same results. The primer used in the extension analysis shown in Fig. $11 \mathrm{~A}$ is complementary to bases 13 to 31 in Fig. 7. The major start site of transcription was preceded by -10 and -35 regions characteristic of a $\sigma^{70}$-dependent promotor (Fig. 12B). The increased expression of the uspA gene during glucose-starvation-induced growth arrest seems to be the result of increased activity of this promoter. This promoter was identified as being active also during

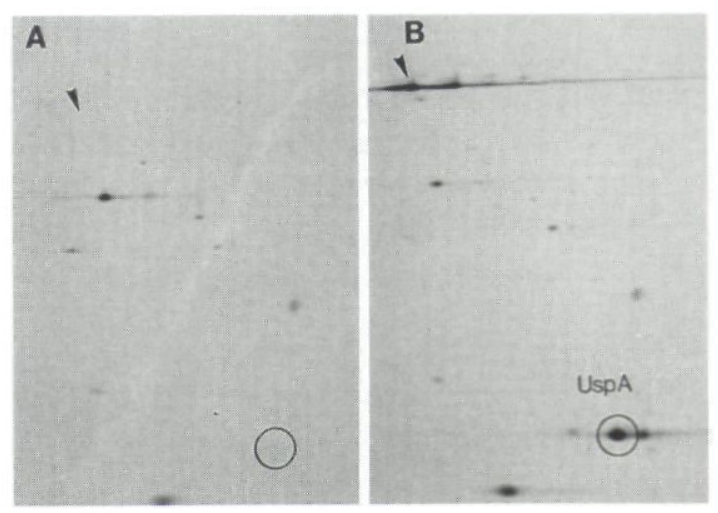

Fig. 6. In vitro transcription translation analysis of clone pTN6091 and the control phagemid pB2SK. Plasmid DNA was purified according to the protocol by Qiagen Inc. Protein expression from the purified DNA was then analysed using the coupled transcription-translation system ( $E$. coli $\mathrm{S} 30$ fraction) of Promega. DNA and the $\mathrm{S} 30$ fraction were mixed and incubated in the presence of $\left[{ }^{35} \mathrm{~S}\right]-$ methionine for $30 \mathrm{~min}$. Samples were subsequently subjected to two-dimensional gel electrophoresis. For details refer to the Experimental procedures. Transcription-translation products of the control phagemid pB2SK without insert DNA is depicted in A, and products of the pTN6091 clone are shown in B. The circled protein spot is UspA and a $42 \mathrm{kDa}$ protein also expressed from the pTN6091 insert DNA is indicated by the arrow. 
-342 CTCCCGATAC GCTGCCAATC AGTTAACACC AGgTCCTGGA GAAACCGCTT TTGTGGTGAC -283

-282 CAACATACGA GCGGCTCTAT AGATAGTGTA GGAGATCAGg TTGTTTTTTT TCCAGAagGT -223

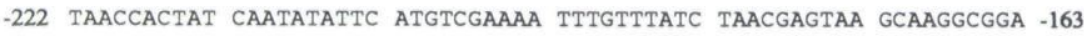

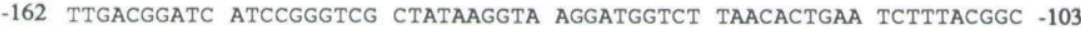

-102 TGGGTTAGCC CCGCGCACGT AGTTCGCAGG ACGCGGGTGA GCTAACGGCA CAAGAAACGC

42 Uspa $\longrightarrow$

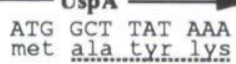
$\mathrm{SD}$

13 CAC ATT CTC ATC GCG GTC GAC CTC TCC CCG GAA AGC AAA GTT CTG GTA

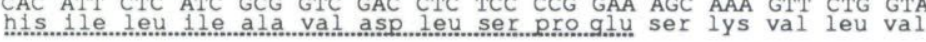

61 GAG AAA GCA GTC TCT ATG GCT CGC CCC TAC AAT GCG AAA GTT TCT CTG glu lys ala val ser met ala arg pro tyr asn ala lys val ser leu

109 ATC CAC GTA GAT GTA AAC TAC TCT GAC CTA TAC ACC GGG CTT ATT GAT 157 GTG AAT CTG GGT GAT ATG CAG AAA CGC ATC TCT GAA GAG ACA CAT CAT
val asn leu gly asp met gln lys arg 11 e ser glu glu thr h1s h1s

205 GCA CTG ACC GAG CTT TCC ACT AAT GCA GGC TAC CCA ATC ACT GAA ACC ala leu thr glu leu ser thr asn ala gly tyr pro 1le thr glu thr

253 CTG AGC GGC AGC GGC GAC CTG GGC CAG GTT CTG GTC GAT GCA ATC AAG leu ser gly ser gly asp leu gly gln val leu val asp ala 1 le 1 ys

301 AAA TAC GAT ATG GAT TTG GTG GTT TGT GGT CAC CAC CAG GAC TTC TGG lys tyr asp met asp leu val val cys gly his h1s gln asp phe trp

349 AGC AAA CTG ATG TCT TCC GCA CGT CAG CTG ATC AAC ACC GTT CAC GTT

397 GAT ATG CTG ATT GTT CCG CTC GCG GAC GAA GAA GAA TAATCTTCCCTCTACG 448 asp met leu 11 e val pro leu ala asp glu glu glu end

449 ACGTGTTCCT GAACGCCCGC ATATGCGGGC GTTTTGCTTT TTGGCGCGCC TTGTTACCTG 508

509 ATCAgCGTAa ACACCTTATC TGGCCTACGg TCtgCGtACG CAATCAAAAT CCCCAGCCAA 568

569 TACAACATTT AACACCATCA TATTTICCAT CATTAGTGTG ATCATCTGGT TATTTTCTGT 628

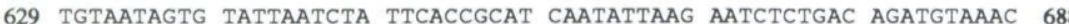

Fig. 7. Sequence of the uspA gene and the predicted amino acid sequence. Residues confirmed by Edman degradation of the purified UspA protein are underlined. A putative Shine-Dalgarno (SD), ribosome-binding sequence upstream of the UspA open reading frame is indicated and an inverted repeat characteristic of a rho-independent terminator is underlined with arrowheads. This sequence appears in the EMBL/GenBank/ DDBJ Nucleotide Sequence Data Libraries under the accession number $\mathrm{X} 67639$. steady-state growth (not shown). Two minor start points were identified eight and 10 bases downstream of the major start point at position-131 (Fig. 11A and B).

\section{Discussion}

In this paper we report the mapping and cloning of a gene encoding a small, soluble $E$. coli protein that responds to diverse stresses. The gene, designated uspA, was cloned from the Kohara library using a degenerate oligonucleotide probe based on the $\mathrm{N}$-terminal sequence of the protein purified by 2-D gel electrophoresis. The uspA gene was found to be present within the overlap region between the Kohara transducing phages $12 \mathrm{E} 4$ and $6 \mathrm{~A} 4$, and is located at $77 \mathrm{~min}$ on the E. coli W3110 chromosome (Fig. 5). The location of the uspA gene in a $5.2 \mathrm{~kb}$ $P s t$ fragment of Kohara phage 6A4 was confirmed by in vitro transcription-translation analysis of the purified DNA fragment and by nucleotide sequencing. The calculated isoelectric point of 5.2 is in good agreement with the isoelectric point of 5.36 estimated from the position of the denatured protein after isoelectric focusing. The deduced
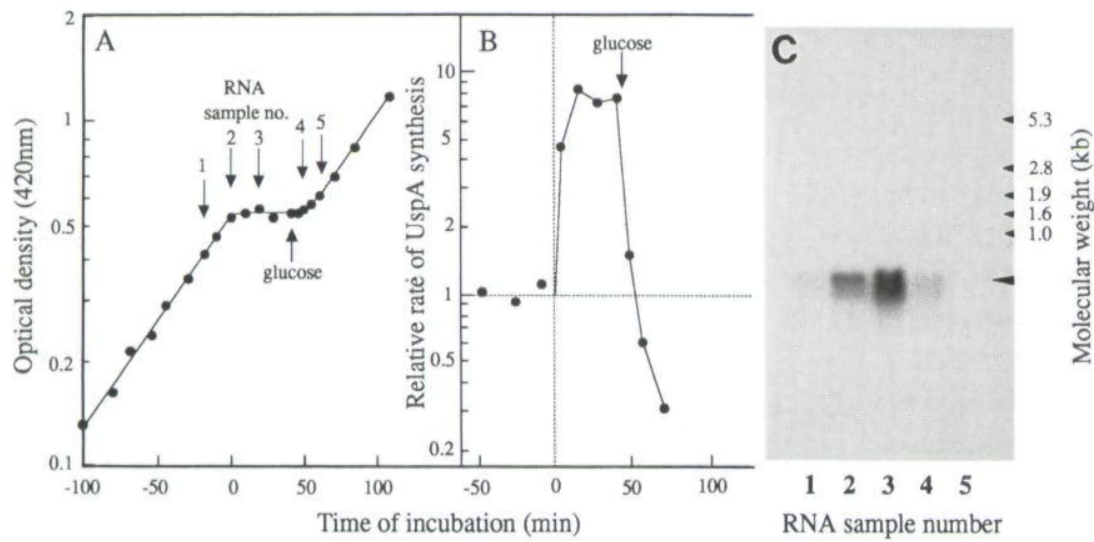

Fig. 8. Growth (A), UspA expression (B), and lev els of uspA transcript (C), during glucose starvation and recovery from glucose starvation. E. coli W3110 was grown in glucose limited MOPS at $37^{\circ} \mathrm{C}$. Glucose $(0.4 \%)$ was added back to the culture $40 \mathrm{~min}$ after growth arrest as a result of glucose exhaustion. The relative rates of UspA synthesis were determined as described in Fig. 1 and the Experimental procedures. RNA was collected from the cultures for Northern blot analysis at times indicated in $\mathrm{A}$. 


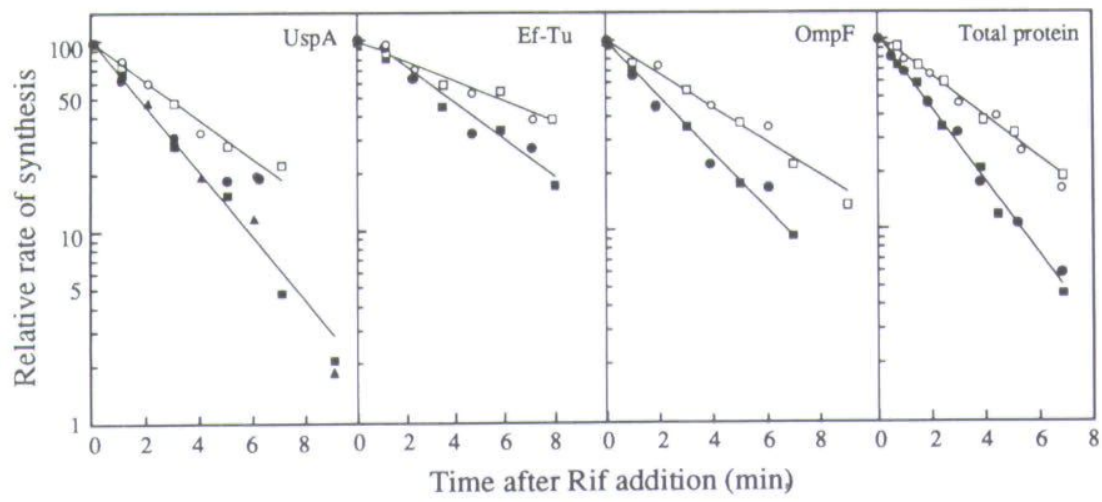

Fig. 9. Residual UspA, Ef-Tu, OmpF and total protein synthesis after inhibition of transcription with rifampicin $\left(200 \mu \mathrm{g} \mathrm{ml}^{-1}\right)$ during steady-state growth of E. coli AS19 in glucose-minimal medium (closed symbols) $\left(37^{\circ} \mathrm{C}\right)$ and after $20 \mathrm{~min}$ of glucose starvation (open symbols). At time zero, rifampicin was added, and at indicated times samples were taken, pulse-labelled with $\left[{ }^{3} \mathrm{H}\right]$ leucine, proteins separated by two-dimensional gel electrophoresis and the differential rates of synthesis determined as described in the Experimental procedures. Rates are given relative to that at zero time. molecular mass of the UspA protein, determined by nucleotide sequencing of the gene, is $15.8 \mathrm{kDa}$. This molecular mass of the deduced UspA protein deviates somewhat from the $13.5 \mathrm{kDa}$ estimated from the migration of UspA (C13.5) on a SDS polyacrylamide gel (VanBogelen et al., 1990). However, such discrepancy between the deduced and the estimated molecular mass is not unusual for proteins in the 10-20 kDa range (VanBogelen et al., 1990). The sequence analysis revealed also that uspA is a previously unidentified gene on the E. coli chromosome and the deduced amino acid sequence shows no significant homology with any other known protein in the databanks searched (EMBL/Genbank/DDBJ Libraries). The presence of a transcriptional start point $131 \mathrm{bp}$ upstream of the translational start point (Figs 7 and 11), the rho-independent terminator $23 \mathrm{bp}$ downstream of the stop codon (Fig. 7), and the size of the uspA transcript (Fig. $8 \mathrm{C}$ ) suggest that the gene is monocistronically expressed.

Analysis of the pattern of induction of protein UspA under several starvation and stress conditions allows us to conclude that the protein is a general, non-specific responder to growth arrest or to perturbations in unrestricted balanced growth. The protein was found to be induced three to ninefold by all the stress conditions so far examined except for a temperature shift from 37 to $10^{\circ} \mathrm{C}$. The induction appeared as soon as the growth rate fell below the maximal growth rate supported by the medium and peaked within 20 min after a change in the growth rate was observed. In addition, by using an experimental system in which growth and the cellular levels of $\operatorname{ppGpp}(\mathrm{p})$ are under control of a $\mathrm{P}_{t a c}:$ :relA fusion (Schreiber et al., 1991), we demonstrated that cessation of growth causes the induction of UspA when there are no known changes in nutritional status of the growth medium (Fig. 2). Furthermore, this induction appears not to be a direct effect of $\mathrm{ppGpp}(\mathrm{p})$ acting on uspA transcription or translation since UspA was demonstrated to be induced also in a $\Delta r e l A / s p o T$ mutant during glucose starvation
(Fig. 2B), isoleucine starvation and SHMT treatment (not shown).

The increased level of protein UspA, as detected by Coomassie brilliant blue staining of 2-D gels (not shown), during growth inhibition appears to be primarily a result of transcriptional activation of the corresponding gene (Fig. 8). Alterations in UspA stability (Fig. 10) or the functional half-life of the uspA transcript (Fig. 9) do not participate appreciably in regulating the levels of the protein during growth arrest as a result of carbon (glucose) starvation. The feedback mechanism bringing the level of UspA back to appropriate levels during recovery and regrowth of cells appears also to be a result of transcriptional control. While the level of the uspA transcript decreased rapidly as a result of resupply of glucose to carbon (glucose) starved cells (Fig. $8 \mathrm{C}$ ), the stability of

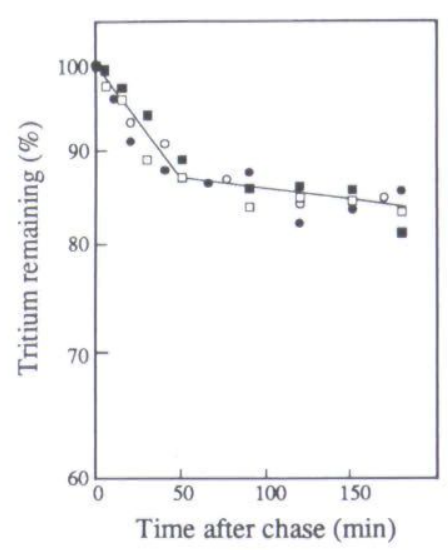

Fig. 10. UspA stability in E. coli W3110 cells growing exponentially in glucose minimal MOPS $(\bullet)$, starved $10 \mathrm{~min}$ for glucose $(\mathrm{O})$, starved $60 \mathrm{~min}$ for glucose $(\square)$, or subjected to glucose upshift conditions ( $\mathbf{\square})$. Cultures were pulse-labelled for $5 \mathrm{~min}$ with $\left[{ }^{3} \mathrm{H}\right]$-leucine and chased with nonradioactive leucine $(2.4 \mathrm{mM})$. Samples $(0.5 \mathrm{ml})$ were removed at indicated times after the chase, mixed with $0.5 \mathrm{ml}$ of a culture of the same strain grown in $\left[{ }^{35} \mathrm{~S}\right]$-methionine labelling medium, subjected to twodimensional gel electrophoresis, and specific protein spots were subsequently recovered from gels for determination of the remaining tritium. For details refer to the Experimental procedures. 
A

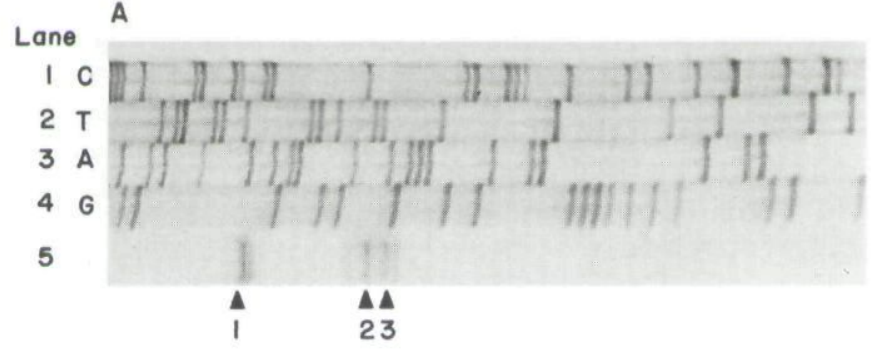

B

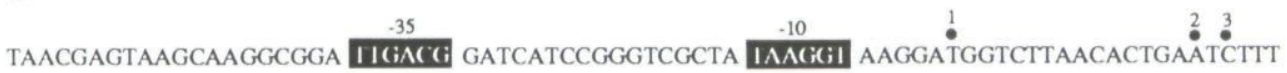

ACGGCTGGGTTAGCCCCGCGCACGTAGTTCGCAGGACGCGGGTGAGCTAACGGCACAAGAAACGCTAGCTGGCCAGT

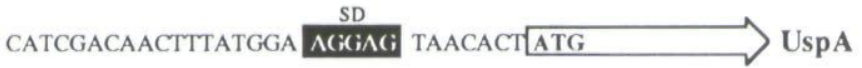

Fig. 11. A. Primer extension analysis of uspA transcripts. RNA was isolated from E. coli W3110 growing at steady-state in glucose minimal MOPS and at times during glucose starvation. A radiolabelled oligonucleotide was incubated with the RNA, and reverse transcriptase was added to produce a DNA copy of the transcript, as described in the Experimental procedures. The same oligonucleotide was used to prime dideoxy sequencing products from a DNA template (pN6091) that contains the uspA gene. The letters beside each lane indicate the dideoxynucleotide used to terminate each reaction. Lane 5, RNA isolated from 30-min glucose-starved cells.

B. Nucleotide sequence of the upstream and downstream regions flanking the transcriptional start site of $u s p A$. The putative ribosome-binding site (SD), and the -10 and -35 regions are boxed. The transcriptional start points 1,2 and 3 are those depicted in $A$. The arrow indicate the translational start site of UspA.

the UspA protein (Fig. 10), and the uspA transcript (not shown) appeared to be unaffected. Thus, we conclude that the adjustment in the levels of UspA protein during regrowth of cells is primarily a result of dilution of the protein after shut-down of uspA transcription.

Some of the genes found to be transcriptionally activated when $E$. coli enters starvation-induced post-exponential phase have been suggested previously to be nonspecific responders to growth inhibition (Aldea et al., 1990). These genes are driven by so called 'gearbox' promotors. Gearboxes denote a distinct class of promoters characterized by showing an activity that is inversely dependent on growth rate (Aldea et al., 1990; Conell et al., 1987). Thus far, the cell division ftsQAZ gene cluster, the bolA morphogene (Aldea et al., 1990) and the $m c b A$ gene encoding Microcin B17 (Conell et al., 1987) have been found to be driven by 'gearboxes'. The promoters of these genes share some additional features including conserved and characteristic sequences around their -10 and -35 regions (Aldea et al., 1990). The induction of expression of these genes during entrance into starvation-induced post-exponential phase has been interpreted as being a consequence of the activation of gearbox promoters caused by the gradual decrease in growth rate that occurs during growth-rate transition (Aldea et al., 1990). However, the regulation of the gene uspA seems to be distinct from gearbox regulation. First, the expression of UspA is not inversely dependent on growth rate.
The expression of UspA is essentially indistinguishable in $E$. coli growing with doubling times $(\tau)$ between 55 min (glucose-minimal MOPS) and $7 \mathrm{~h}$ (L-serine-minimal MOPS; Fig. 3). Second, primer extension analysis showed that the increased transcription of the gene uspA, at least during carbon (glucose) starvation, is a result of the activation of a $\sigma^{70}$-dependent 'housekeeping' promoter.

To address the question whether uspA is regulated by any or several of the known master regulators of global regulatory networks, we examined the effects of mutations in a number of global regulatory loci on UspA expression. The mutations in the loci examined did not appreciably affect the synthesis of UspA (Table 1). Although we have not tested the effect of mutations in cya or crp on UspA expression, we believe that the universal property of uspA of responding to diverse stresses rules out catabolite repression as the sole mechanism for uspA regulation. It is possible, however, that the CAP-CAMP complex acts as an enhancer during some of the conditions demonstrated to induce UspA synthesis.

We have initiated mutational analysis of the uspA gene to learn whether the protein is essential for the cell either during growth or growth arrest, and in general the effects on the cell of a deficiency of the protein. We also placed the cloned gene under control of a conditional inducible promoter to examine the effects of overproduction of the protein. Results from these experiments will determine 
the optimal pathway for learning (i) the mechanisms of regulation of the gene on a molecular basis and, (ii) the function of its product.

\section{Experimental procedures}

\section{Bacterials strains, and plasmids}

E. coli strains used in this study are listed in Table 2. The K-12 strain of E. coli, W3110 (Smith and Neidhardt, 1983), was used except where noted. E. coli W3110 was used also as the source for isolating the UspA protein and chromosomal DNA used for Southern analysis and creating genomic libraries. The Bluescript II SK+ phagemid (pB2SK; Stratagene) was used as the cloning vector.

\section{Media and growth conditions}

Cultures were grown in liquid MOPS medium (Neidhardt et al., $1974)$ supplemented with glucose $(0.4 \%)$ and thiamine $(10 \mathrm{mM})$ for minimal medium or glucose $(0.4 \%), 20$ amino acids, four nucleotides, and five vitamins (Wanner et al., 1977) for rich medium, in Erlenmeyer flasks placed in a rotary shaker at indicated temperatures. When required, the MOPS minimal medium was supplemented with various carbon sources as described by Wanner et al. (1977) to obtain different growth rates. Luria broth agar for plates was prepared as described by Sambrook et al., (1989). When appropriate, the Luria broth medium was supplemented with carbenicillin $\left(50 \mu \mathrm{g} \mathrm{ml}^{-1}\right)$, and/ or X-gal $\left(0.8 \mathrm{mg} \mathrm{plate}^{-1}\right)$. For analysis of proteins induced by starvation (nitrogen, phosphate, carbon (glucose), or sulphate), cells were grown aerobically in glucose minimal MOPS,

Table 2. E. coli strains used in this study.

\begin{tabular}{|c|c|c|}
\hline $\begin{array}{l}\text { Strains/ } \\
\text { Plasmids }\end{array}$ & Genotype/Description & Source \\
\hline W3110 & Wild type & Our lab. \\
\hline CF1948 & As W3110, but $\Delta$ relA, $\Delta$ spoT & M. Cashel \\
\hline MP180 & Wild type & P.C. Loewen \\
\hline UM122 & As MP180, but katF::Tn10 & P.C. Loewen \\
\hline TC3616 & thi-1, leu-6, lavY1, supE44, tonA21 & T. Atlung \\
\hline TC3617 & As TC3616, but appY::kan & T. Atlung \\
\hline GM37 & 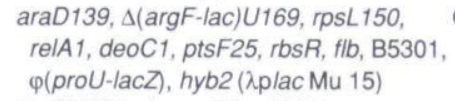 & C.F. Higgins \\
\hline GM230 & As GM37,but osmZ(hns)200 & C.F. Higgins \\
\hline SC122 & $\begin{array}{l}\text { lac(am), trp(am), pho(am), supC(ts), } \\
\text { rpsL, mal(am) }\end{array}$ & Our lab. \\
\hline K165 & As SC122, but rpoH165(am) & Our lab. \\
\hline ZK242 & $\begin{array}{l}\text { As W3110, but } \Delta / a c U 169, \text { tra2, } \\
\text { mal::Tn10, ompR101 }\end{array}$ & R. Kolter \\
\hline BE1 & As W3110, but Irp201::Tn10 & R.G. Matthews \\
\hline BW3414 & $\Delta($ argF-lac)205(U169) & Our lab. \\
\hline BW3820 & As BW3414, but phoB23 & Our lab. \\
\hline $\mathrm{DH} 5 \alpha \mathrm{F}^{\prime}$ & $\begin{array}{l}\text { supE44, } \triangle \text { lacU169 (Ф80lacZ } \triangle \mathrm{M} 15) \text {, } \\
\text { hsdR17, recA1, endA1, gyrA96, } \\
\text { thi-1, relA1 }\end{array}$ & Our lab. \\
\hline AS19 & Enhanced permeability to antibiotics & Our lab. \\
\hline pSM11 & $\mathrm{P}_{\text {tac }}-$ relA fusion carried on pKK223-3 & Schreiber et al. (1991) \\
\hline pKK223-3 & tac promoter expression vector & Pharmacia LKB \\
\hline pB2SK & $\begin{array}{l}\text { pBluescript II SK ( } \pm \text { ) phagemid } \\
\text { cloning vector }\end{array}$ & Stratagene \\
\hline
\end{tabular}

or in M9 minimal medium (Sambrook et al., 1989) in the case of sulphate starvation with one-twentieth the normal concentration of the appropriate nutrient. This procedure resulted in growth arrest of cells at an $\mathrm{OD}_{420}$ of $0.5-0.65\left(1.5-2 \times 10^{8}\right.$ cells $\mathrm{ml}^{-1}$ ). Isoleucine starvation, temperature shifts, treatment with cadmium chloride, hydrogen peroxide, $A C D Q$, nalidixic acid (VanBogelen et al., 1987), serine hydroxamate (SHMT) (Metzger et al., 1989), and osmotic challenge (Jenkins et al., 1990) were performed as previously described. Cultures grown in glucose minimal MOPS ( $\mathrm{pH} 7.2$ ) were challanged with acid by adding $1 \mathrm{M} \mathrm{HCl}$ to the medium to reach a final $\mathrm{pH}$ of $5.5-5.7$. Cycloserine and dinitrophenol (DNP) were added to give a final concentration of $1 \mathrm{mg} \mathrm{ml}^{-1}$ and $0.5 \mathrm{mM}$ respectively. Inhibitors were added when cultures reached an $\mathrm{OD}_{420}$ of 0.5 .

\section{Resolution of proteins on two-dimensional polyacrylamide gels}

Cell extracts for two-dimensional polyacrylamide gels were prepared by the methods of O'Farrell (1975) with modifications (VanBogelen and Neidhardt, 1990).

\section{Measurement of rates of synthesis of individual proteins}

At indicated times, a portion (1 $\mathrm{ml})$ of a culture was removed and placed in a flask containing $\left[{ }^{3} \mathrm{H}\right]$-leucine $\left(5 \mathrm{mCi} \mathrm{mmol}^{-1}\right.$, $100 \mu \mathrm{Ci} \mathrm{ml}^{-1}$ ). Incorporation was allowed to proceed for $5 \mathrm{~min}$, after which non-radioactive leucine $(2.4 \mathrm{mM})$ was added for a 3-min chase. To this sample was added a portion of a culture of the same strain grown in $\left[{ }^{35} \mathrm{~S}\right]-$ methionine labelling medium (glucose minimal MOPS; $1.1 \mathrm{mCi} \mathrm{mmol}^{-1}, 11 \mathrm{mCi} \mathrm{ml}^{-1}{ }^{35} \mathrm{~S}$ methionine). The mixed sample was analysed by resolution on two-dimensional gels and autoradiograms were prepared to permit visualization of labelled proteins. Protein spots chosen for quantitative assay were sampled from the dried gel with a syringe needle and treated as described by Pedersen et al. 1976) to permit measurement of their ${ }^{3} \mathrm{H}$ and ${ }^{35} \mathrm{~S}$ content by scintillation counting. The differential rate of synthesis of a sampled protein was defined as the ${ }^{3} \mathrm{H} /{ }^{35} \mathrm{~S}$ ratio of the sampled spot divided by the same isotope ratio of unfractionated, trichloroacetic acid (TCA)-precipitated extracts.

\section{Determination of protein stability}

For UspA stability measurements, a $10-\mathrm{ml}$ sample of culture was pulse-labelled for $5 \mathrm{~min}$ with $\left[{ }^{3} \mathrm{H}\right]$-leucine $\left(5 \mathrm{mCi} \mathrm{mmol}^{-1}\right.$, $\left.100 \mu \mathrm{Ci} \mathrm{ml}{ }^{-1}\right)$ and chased with non-radioactive leucine (2.4 $\mathrm{mM})$. Samples $(0.5 \mathrm{ml})$ were removed at indicated times after the start of the chase, mixed with $0.5 \mathrm{ml}$ of a culture of the same strain grown in $\left[{ }^{35} \mathrm{~S}\right]$-methionine labelling medium, subjected to two-dimensional gel electrophoresis, and specific protein spots were subsequently recovered from gels for determination of the ${ }^{3} \mathrm{H} /{ }^{35} \mathrm{~S}$ ratios as described above.

\section{Determination of functional mRNA half-lifes}

The mRNA half-lives were determined as the decay rate of the potential to synthesize specific proteins after complete inhibition of the initiation of transcription by RNA polymerase by use 
of the antibiotic rifampicin $\left(200 \mu \mathrm{g} \mathrm{ml}^{-1}\right)$ as described by Pedersen et al. (1978).

\section{Sample preparation for protein microsequencing}

Cultures induced for the UspA protein were harvested and fractionated to obtain the soluble fraction as described (Achtman et al., 1983). The soluble protein fraction was concentrated 100 fold by ultrafiltration through polyethersulphone membranes with different nominal molecular limits (Omega membrane; Pharmacia LKB). The UspA protein was recovered in the highmolecular-mass $(>50 \mathrm{kDa}$ ) fraction of this native cell extract and this fraction was then subjected to two-dimensional gel electrophoresis (150-200 $\mu \mathrm{g}$ total protein loaded on each gel). After electrophoresis, the gels were soaked in transfer buffer (10 mM 3-(cyclohexylamino)-1-propanesulphonic acid, 10\% methanol, $\mathrm{pH}$ 11.0) for $10 \mathrm{~min}$ to reduce the amount of glycine and Tris contaminations. PVDF Immobilon (Millipore) membranes were rinsed with $100 \%$ methanol and stored in transfer buffer. The gels, sandwiched between sheets of PVDF membrane and several sheets of blotting paper (Whatman), were assembled into a blotting apparatus and electroeluted for 30 $\mathrm{min}$ at $50 \mathrm{~V}(170-100 \mathrm{~mA})$ in transfer buffer. The PVDF membranes were washed in sterile deionized water for $10 \mathrm{~min}$, dried at room temperature and subjected to autoradiography. The UspA protein spot was identified and excised from the blot. Determination of the $\mathrm{N}$-terminal amino acid sequence of the UspA protein was then performed by automated Edman degradation directly on the membrane fragment (University of Michigan Medical School, core facility). A 72-fold degenerate 20-mer oligonucleotide probe was then synthesized based on the $\mathrm{N}$ terminal sequence data and 5 '-labelled using T4 polynucleotide kinase (New England Biolabs) and $\left[\gamma^{32} \mathrm{P}\right]$-ATP ( $5000 \mathrm{Ci} \mathrm{mmol}^{-1}$; New England Nuclear) according to the protocol by Sambrook et al. (1989).

\section{DNA manipulations}

DNA and RNA purifications, ligations, restriction analyses and gel electrophoresis were carried out as described by Sambrook et al. (1989). Southern and Northern blot analysis was carried out as described by Southern (1975) and Sambrook et al. (1989). Colony hybridization of cells carrying the pB2SK phagemid with insert DNA was carried out after restreaking transformants on nitrocellulose sheets placed on LB-carbenicillin $\left(50 \mu \mathrm{g} \mathrm{ml}^{-1}\right)$ plates. After overnight growth, the sheets were transferred to LB-chloramphenicol $\left(100 \mu \mathrm{g} \mathrm{ml}^{-1}\right)$ plates for $12 \mathrm{~h}$ to amplify the phagemid copy number in the cells. The nitrocellulose sheets were then baked and washed as described (Sambrook et al., 1989), and hybridized using the degenerate oligonucleotide probe described in Results. An ordered array of $\lambda$-phage clones (Kohara et al., 1987) immobilized onto a sheet of positively-charged nylon membrane (Gene Mapping Membrane) was purchased from Takara Biochemical Inc. $\lambda$-Phage DNA was purified from Kohara clones using the protocol provided by Qiagen Inc. DNA sequencing, using the Sanger dideoxy chain termination method and $\left[{ }^{35} \mathrm{~S}\right]$ ATP was carried out with Sequenase ${ }^{T M}$ from United States Biochemicals (USB) according to the manufacturer's instructions. Restriction enzymes, T4 DNA ligase and T4 polynucleotide kinase were products of New England Biolabs and
Boehringer Mannheim Co. In vitro transcription-translation analysis of cloned DNA was performed using the Promega $E$. coli S30 coupled transcription-translation system according to the protocol provided by the manufacturer.

\section{Promoter mapping}

Oligonucleotide primers were end-labelled by using $50 \mu \mathrm{Ci}$ of $\left[\gamma^{32} \mathrm{P}\right]-\mathrm{ATP}\left(5000 \mathrm{Ci} \mathrm{mmol}^{-1}\right)$ and T4 polynucleotide kinase as described (Sambrook et al., 1989). Labelled primer (0.02-0.05 pmol) was added to $E$. coli RNA in a $10-\mu$ reaction volume containing $0.05 \mathrm{M}$ Tris $\mathrm{HCl}(\mathrm{pH} 8.2)$ and $0.1 \mathrm{M} \mathrm{KCl}$. Reaction mixtures were incubated at $90^{\circ} \mathrm{C}$ for $1 \mathrm{~min}, 60^{\circ} \mathrm{C}$ for $2 \mathrm{~min}$, and then on ice for $15 \mathrm{~min}$ to allow annealing of primer to template. Six microlitres of the annealing reaction mixes were added to tubes containing $1 \mu \mathrm{l}$ of $2.5 \mathrm{mM}$ dATP, dCTP, dGTP, and dTTP mix; $2 \mu$ of reverse transcriptase buffer $(0.25 \mathrm{M}$ Tris $\mathrm{HCl}[\mathrm{pH}$ 8.2 ], $0.2 \mathrm{M} \mathrm{KCl}, 0.036 \mathrm{M} \mathrm{Mg}$ acetate, $0.01 \mathrm{M}$ dithiothreitol, and $1 \mu \mathrm{l}(8 \mathrm{U})$ of avian myeloblastosis virus reverse transcriptase (Life Sciences, Inc.). Reaction mixtures were incubated at $48^{\circ} \mathrm{C}$ for $45 \mathrm{~min}$, and then $4 \mu \mathrm{l}$ of Sequenase stop buffer (USB) was added to terminate reactions. The primer extension reaction mixtures $(2.5-6.0 \mu \mathrm{l})$ were subjected to electrophoresis next to a sequencing ladder of the end-labelled fragment in $5 \%$ polyacrylamide gels containing $8 \mathrm{M}$ urea followed by autoradiography.

\section{Acknowledgements}

This work was supported by Public Health Service grant GM17892 from the National Institutes of Health to F.C.N. T.N. was supported by a stipend from the Swedish Natural Science Research Council.

We are grateful to M. Koomey, in whose laboratory parts of this work were performed, for helpful advice, and to N.H. Albertson for assistance and valuable comments on the manuscript. We thank T. Atlung, M. Cashel, C. F. Higgins, R. Kolter, P. C. Loewen, and R. G. Matthews, for supplying strains and D. J. Gage and R. A. VanBogelen for sharing unpublished results.

\section{References}

Achtman, M., Mercer, A., Kusecek, B., Pohl, A., Heuzenroeder, M., Aaronson, W., Sutton, A. and Silver, R.P. (1983) Six widespread bacterial clones among Escherichia coli $\mathrm{K} 1$ isolates. Infect Immun 39: 315-335.

Aldea, M., Garrido, T., Pla, J., and Vincente, M. (1990) Division genes in Escherichia coli are expressed coordinately to cell septum requirements by gearbox promotors. EMBO $\mathrm{J} 11$ : 3787-3794.

Atlung, T., Nielsen, A., and Hansen, F.G. (1989) Isolation characterization, and nucleotide sequence of app $Y$, a regulatory gene for growth-phase-dependent gene expression in Escherichia coli. J Bacteriol 171: 1683-1691.

Bachmann, B.J. (1990) Linkage map of Escherichia coli K-12, edition 8. Microbiol Rev 54: 130-197.

Conell, N., Han, Z., Moreno, F., and Kolter, R. (1987) An E. coli promotor induced by the cessation of growth. Mol Microbiol 1: 195-201. 
Ernsting, B.R., Atkinson, M.R., Ninfa, A.J., and Matthews, R.G. (1992) Characterization of the regulon controlled by the leucine-responsive regulatory protein in Escherichia coli. $J$ Bacteriol 174: 1109-1118.

Gallant, J.A. (1975) Stringent control in Escherichia coli. Ann Rev Genet 13: 393-415.

Groat, R.G., Schultz, J.E., Zychlinsky, E., Bockman, A., and Matin, A. (1986) Starvation proteins in Escherichia coli: Kinetics of synthesis and role in starvation survival. J. Bacteriol 168: 486-493.

Hall, C.B., and Silhavy, T.J. (1981) The ompB locus and the regulation of the major outer membrane porin proteins of Escherichia coli K12. J Mol Biol 146: 23-43.

Higgins, C.F., Dorman, C.J., Stirling, D.A., Waddell, L., Booth, I.R., May, G., and Bremer, E. (1988) A physiological role for DNA supercoiling in the osmotic regulation of gene expression in S. typhimurium and E. coli. Cell 52: 569-584.

Jenkins, D.E., Schultz, J.E. and Matin, A. (1988) Starvationinduced cross protection against heat or $\mathrm{H}_{2} \mathrm{O}_{2}$ challenge in Escherichia coli. J. Bacteriol 170: 3910-3914.

Jenkins, D.E., Chaisson, S.A., and Matin, A. (1990) Starvation induced cross protection against osmotic challenge in Escherichia coli. J Bacteriol 172: 2779- 2781.

Kjelleberg, S., Hermansson, M., Mårdén, P. and Jones, G.W. (1987) The transient phase between growth and nongrowth of heterotrophic bacteria, with special emphasis on the marine environment. Ann Rev Microbiol 41: 25-49.

Kohara, Y., Akiyama, K., and Isono, K. (1987) The physical map of the whole Escherichia coli chromosome: Application of a new strategy for rapid analysis and sorting of a large genomic library. Cell 50: 495-508.

Lange, R., and Hengge-Aronis, R. (1991a) Identification of a central regulator of stationary phase gene expression in Escherichia coli. Mol Microbiol 5: 49-59.

Lange, R., and Hengge-Aronis, R. (1991b) Growth phase regulated expression of bolA and morphology of stationaryphase Escherichia coli cells are controlled by the novel sigma factor $\sigma^{\mathrm{s}}$. J Bacteriol 173: 4474-4481.

Magasanik, B., and Neidhardt, F.C. (1987) Regulation of carbon and nitrogen utilization. In Escherichia coli and Salmonella typhimurium: Cellular and Molecular Biology, Neidhardt, F.C., Ingraham, J.L., Low, K.B., Magasanik, B., Schaechter, M., and Umbarger, H.E. (eds). Washington, D.C.: American Society for Microbiology, pp. 1318-1325.

Metzger, S., Sarubbi, E., Glaser, G., and Cashel, M. (1989) Protein sequence encoded by the relA and the spoT genes of Escherichia coli are interrelated. $J$ Biol Chem 264: 9122-9125.

Mulvey, M.R., and Loewen, P.C. (1989) Nucleotide sequence of katF of Escherichia coli suggests KatF protein is a novel sigma transcription factor. Nucl Acids Res 17: 9979-9991.

Neidhardt, F.C., Bloch, P.L., and Smith, D.F. (1974) Culture medium for enterobacteria. J Bacteriol 119: 736-747.

Neidhardt, F.C., VanBogelen, R.A., and Vaughn, V. (1984) The genetics and regulation of heat shock proteins. Ann Rev Genet 18: 295-329.
O'Farrell, P.H. (1975) High resolution two-dimensional electrophoresis of proteins. J Biol Chem 250: 4007-4021.

Pedersen, S., Reeh, S.V., Parker, J., Watson, R.J., Friesen, J.D., and Fiil, N.P. (1976) Analysis of the proteins synthesized in ultraviolet light-irradiated Escherichia coli following infection with the bacteriophage $\lambda d$ rifd 18 and $\lambda d f u s-3 . M o l$ Gen Genet 144: 339-344.

Pedersen, S., Reeh, S., and Friesen, J.D. (1978) Functional mRNA half-lives in Escherichia coli. Mol Gen Genet 166: 329-336.

Sak, B. D., Eisenstark, A., and Touati, D. (1989) Exonuclease III and the catalase hydroperoxidase II in Escherichia coli are both regulated by the katF product. Proc Natl Acad Sci USA 86: 3271-3275.

Sambrook, J., Fritsch, E.F., and Maniatis, T. (1989) Molecular Cloning: A Laboratory Manual, 2nd edn. Cold Spring Harbor, New York: Cold Spring Harbor Laboratory Press.

Schreiber, G., Metzger, S., Aizenman, E., Roza, S., Cashel, M., and Glaser, G. (1991) Pleiotropic effects of overexpression of the relA gene in Escherichia coli. J Biol Chem 266: 3760-3767.

Smith, M.W., and Neidhardt, F.C. (1983) Proteins induced by anaerobiosis in Escherichia coli. J Bacteriol 154: 336-343.

Southern, E.M. (1975) Detection of specific sequences among DNA fragments seperated by gel electrophoresis. $\mathrm{J} \mathrm{Mol} \mathrm{Biol}$ 98: 503-518.

Spassky, A., Rimsky, S., Garreau, H, and Buc, H. (1984) H1a, an E. coli DNA-binding protein which accumulates in stationary phase, strongly compacts DNA in vitro. Nucl Acids Res 12: $5321-5340$.

Ullman, A., and Danchin, A. (1983) Role of cAMP in bacteria. Adv. Cyclic Nucleotide Res 15: 1-15.

VanBogelen, R.A., and Neidhardt, F.C. (1990) Ribosomes as sensors of heat and cold shock in Escherichia coli. Proc Natl Acad Sci USA 87: 5589-5593.

VanBogelen, R.A., Kelly, P.M., and Neidhardt, F.C. (1987) Differential induction of heat shock, SOS, and oxidation stress regulons and accumulation of nucleotides in Escherichia coli. J Bacteriol 169: 26-32.

VanBogelen, R.A., Hutton, M.E., and Neidhardt, F.C. (1990) Gene-protein database of Escherichia coli K-12: edition 3. Electrophoresis 11: 1131-1166.

von Ossowski, I., Mulvey, M.R., Leco, P.A., Borys, A., and Loewen, P.C. (1991) Nucleotide sequence of Escherichia coli katE, which encodes catalase HPII. J Bacteriol 173: 514-520.

Wanner, B.L. (1987) Phosphate regulation of gene expression in Escherichia coli. In Escherichia coli and Salmonella typhimurium: Cellular and Molecular Biology, Neidhardt, F.C. Ingraham, J.L. Low, K.B. Magasanik, B. Schaechter, M., and Umbarger, H.E. (eds). Washington, D.C.: American Society for Microbiology, pp. 1326-1333.

Wanner, B.L., Kodaira, R., and Neidhardt, F.C. (1977) Physiological regulation of a decontrolled lac operon. J Bacteriol 130: 212-222. 
Copyright of Molecular Microbiology is the property of Blackwell Publishing Limited and its content may not be copied or emailed to multiple sites or posted to a listserv without the copyright holder's express written permission. However, users may print, download, or email articles for individual use. 